\title{
Hypoxia Induces Alteration of Bone Morphogenetic Protein Receptor Signaling in Pulmonary Artery Endothelial Cell
}

\author{
KUNIHIKO TAKAHASHI, SHIGETOYO KOGAKI, TOHRU MATSUSHITA, SAYAKA NASUNO, SHUNJI KUROTOBI, \\ AND KEIICHI OZONO
}

\author{
Department of Pediatrics, Osaka University Graduate School of Medicine, Suita, Osaka, 565-0871, Japan
}

\begin{abstract}
Reduced expression of bone morphogenetic protein receptors (BMPR) has been implicated in the pathogenesis of pulmonary hypertension $(\mathrm{PH})$, but changes in the intracellular signaling pathway of BMPR have not been fully understood. We hypothesized that BMPR signaling in pulmonary endothelial cells is altered during the development of PH, such as hypoxia-induced $\mathrm{PH}$. We examined the expression of BMPR, BMP-regulated Smads and Id-1 in lung tissues of Sprague-Dawley rats exposed to 2 wk of hypoxia and in isolated lung vascular endothelial cells exposed to hypoxia. BMPRII was predominantly expressed in the endothelial cells (EC) of pulmonary vasculature. In hypoxic rats, reduced expression of BMPRII was observed in the EC of resistance pulmonary arteries. The expression of phosphorylated-Smad1/5/8 and Id-1 in EC was also reduced, whereas the expression of Smad1 as well as activin receptor-like kinase 1 (ALK1) was up-regulated during the development of PH. In in vitro exposure to hypoxia, the expression of mRNA transcripts for BMPRII, Smad8, and Id-1 in EC was reduced, whereas mRNA of Smad1 was not diminished. Our results suggest that hypoxia induces alteration of intracellular BMPR signaling in the EC of resistance pulmonary artery, which is involved in the pathogenesis of $\mathrm{PH}$. (Pediatr Res 61: 392-397, 2007)
\end{abstract}

$I^{\text {Prosing }}$ PAH is a rare, but fatal, disease characterized by remodeling Lof the pulmonary artery leading to right heart failure (1). APAH is also a devastating complication of a variety of diseases, including congenital heart disease, collagen disease, and portal hypertension, affecting the prognosis of these diseases (1). Since the identification of the gene responsible for certain cases of familial and sporadic IPAH as BMPR type II (BMPRII) (2,3), the signaling pathway via BMPR (4) has emerged as one of the potentially important clues to elucidate the fundamental mechanism in PAH. BMPR are composed of type I and type II serine/threonine kinase receptors. Significant reduction of BMPRII protein expression has been shown not only in the lung tissue of IPAH but also in that of APAH without mutations in the BMPRII gene (5). In addition, the amount of BMP type Ia receptor (BMPRIa) has been reported to be reduced in the lung tissues of IPAH as well as APAH (6). Although mice with homozygous mutant alleles for BMPRII were embryonically lethal (lacking mesoderm) (7), mice with a heterozygous mutant have shown increased pulmonary ar-

Received August 25, 2006; accepted November 15, 2006.

Correspondence: Shigetoyo Kogaki, M.D., Department of Pediatrics, Osaka University Graduate School of Medicine, 2-2 Yamada-oka, Suita, Osaka 565-0871, Japan; e-mail: skogaki@ped.med.osaka-u.ac.jp

DOI: $10.1203 /$ pdr.0b013e3180332cba tery pressure, combined with histologic changes (8). These findings indicate that BMPR signaling plays an important role in the common pathobiology of PAH. However, little is known about the role of intracellular signal transducers of BMPR during progression of PAH.

The objective of the present study was to investigate the expression of BMPR signaling-associated molecules in the development of PAH, using a rat model exposed to chronic hypoxia and lung vascular endothelial cell culture system. We demonstrated that hypoxia altered the expression of these molecules in pulmonary artery endothelial cells and the attenuation of BMPR signaling may be involved in the progression of hypoxia-induced $\mathrm{PH}$.

\section{MATERIALS AND METHODS}

Induction of hypoxia-induced pulmonary hypertension in rats. Experiments were performed on male Sprague-Dawley rats, $10 \mathrm{wk}$ old and weighing 300-320 g, with the approval of the Osaka University Medical School Animal Care and Use Committee. Rats were housed for $14 \mathrm{~d}$ in a hypobaric hypoxic chamber, depressurized to $50 \mathrm{kPa}$. Age-matched control rats were maintained in a normoxic chamber. At $0(n=12), 3(n=5), 7(n=5)$, and $14(n=12) \mathrm{d}$ after exposure to hypoxia, the animals anesthetized with an intraperitoneal injection of pentobarbital sodium $(50-60 \mathrm{mg} / \mathrm{kg}$ ). The heart and lungs were removed en bloc and the heart was dissected into the right ventricular free wall (RV), and the left ventricle with the interventricular septum (LV+IVS). The weight ratio of RV to $\mathrm{LV}+\mathrm{IVS}$ was assessed as an indicator of pulmonary hypertension.

Investigation of expression of BMPRII, ALK1, and Smad1/5/8 in lung slices by immunohistochemistry. The left lobe of the lung was inflated with an $18 \mathrm{G}$ cannula to $20 \mathrm{~cm} \mathrm{H}_{2} \mathrm{O}$ and fixed with $4 \%$ paraformaldehyde in PBS. The lungs were paraffin-embedded. Paraffin-embedded sections $(5 \mu \mathrm{m})$ were autoclaved in $0.01 \mathrm{M}$ sodium citrate solution. Endogenous peroxidase was quenched by treatment with $0.3 \% \mathrm{H}_{2} \mathrm{O}_{2}$ in methanol. After blocking, sections were incubated at room temperature for $1 \mathrm{~h}$ with polyclonal anti-BMPRII (1:1000; Santa Cruz Biotechnology, Santa Cruz, CA), anti-Smad5 (1:1000; Santa Cruz Biotechnology), and anti-Smad8 antibody (1:1000; Santa Cruz Biotechnology), or incubated at $4^{\circ} \mathrm{C}$ overnight with monoclonal anti-Smad1 (1:200; Santa Cruz Biotechnology), polyclonal anti-ALK1 (1:1000; Santa Cruz Biotechnology) and anti-phospho-Smad1/5/8 antibody (1:400; Cell Signaling Technology, Beverly, MA). After washing in PBS, biotin-conjugated secondary antibody was incubated for $1 \mathrm{~h}$, followed by incubation with streptavidin-biotinylated HRP complex (Amersham Bioscience, Piscataway, $\mathrm{NJ}$ ) for $1 \mathrm{~h}$ and visualized with 3, 3'-diaminobenzidine (Sigma Chemical Co., St. Louis, MO). Sections were counterstained with Mayer's hematoxylin and examined blind by two observers. Negative controls were performed with nonimmune $\operatorname{IgG}$ instead of the primary antibodies.

Abbreviations: ALK1, activin receptor-like kinase 1; APAH, associated pulmonary arterial hypertension; BMPR, bone morphogenetic protein receptors; EC, endothelial cells; ET1, endothelin 1; IPAH, idiopathic pulmonary arterial hypertension; PAH, pulmonary arterial hypertension; PASMC, pulmonary artery smooth muscle cells; PH, pulmonary hypertension; TRLEC, SV-40 transformed rat lung vascular endothelial cells 
Morphometric analysis of BMPRII and Smad protein expressions in tissue slices. Semiquantitation of BMPRII, Smad1, Smad5, and Smad8 expression was performed using a Macscope Analyzer (Mitani Corporation, Fukui, Japan). Five fields including the small muscular pulmonary arteries in each slide were randomly selected under \pm 1000 magnification and recorded as digital image files. The outer and inner circumference of the vascular intima was carefully traced on the monitor, and the total area of endothelium was measured. The area of positive staining was measured based on the predetermined color and the ratio of positive staining area to the total endothelial area was calculated.

In situ hybridization. Sense and antisense probes, labeled with digoxigenin-UTP (Roche Diagnostics, Penzberg, Germany), were prepared from a 519-bp PCR fragment between nucleotides 1362 and 1900 of the rat Smad1 sequence. In situ hybridization was performed using the MicroProbe staining system (Fisher Scientific, Pittsburgh, PA), with modifications (9). Tissue sections were rapidly dewaxed, cleared with alcohol, dehydrated, and digested with proteinase $\mathrm{K}$ at $37^{\circ} \mathrm{C}$ for $15 \mathrm{~min}$. The probe was applied in Brigati Probe dilution (Falma, Tokyo, Japan), and allowed to hybridize at $50^{\circ} \mathrm{C}$ for $2 \mathrm{~h}$. The binding probe was detected with anti-digoxigenin ALP-conjugate antibody (Roche Diagnostics) and visualized using a chromogenic substrate BCIP/NT. Sections were counterstained with neutral red.

Protein isolation and Western blotting. Whole rat lungs were homogenized in RIPA buffer (10 mM Tris, $150 \mathrm{mM} \mathrm{NaCl}, 5 \mathrm{mM}$ EDTA, $1 \%$ Triton $\mathrm{X}-100,1 \%$ sodium deoxycholate, and $1 \%$ SDS) in the presence of $1 \mathrm{mM}$ sodium orthovanadate, $5 \mathrm{mM} \mathrm{NaF}$, and protease inhibitors (Roche Diagnostics). The protein content was determined by the Bio-Rad DC protein assay. From each cell lysate, $20 \mu \mathrm{g}$ of protein was electrophoresed in a $10 \%$ SDS-polyacrylamide gel and the separated proteins were electrophoretically transferred to a polyvinylidene fluoride membrane. After the inhibition of nonspecific binding with 5\% nonfat-milk in TBS containing $0.1 \%$ Tween 20 , the membrane was reacted with anti-phospho-Smad1/5/8 antibody (1:1000) or anti-ALK1 antibody $(1: 250)$ at $4^{\circ} \mathrm{C}$ overnight. After secondary antibody (1:2000) was applied, the immune complexes were detected with an ECL kit (Amersham Bioscience). Densitometry was performed with NIH Image software (National Institutes of Health, Baltimore, MD).

Semiquantitative PCR. Total RNA was isolated from whole lung tissues using a commercial reagent (Isogen; Nippon Gene, Toyama, Japan). One microgram total RNA was subjected to first-strand synthesis using Superscript II reverse transcriptase (Invitrogen Corp., Carlsbad, CA) and random hexamers at $37^{\circ} \mathrm{C}$ for $2 \mathrm{~h}$. The reaction was stopped by incubation at $70^{\circ} \mathrm{C}$ for $10 \mathrm{~min}$. Amplification of Id-1 cDNA was achieved using specific primers based on a published GenBank sequence (Table 1). After the first denaturation at $94^{\circ} \mathrm{C}$ for 7 min, PCR cycles were performed with the sequence of $94^{\circ} \mathrm{C}$ for $1 \mathrm{~min}, 58^{\circ} \mathrm{C}$ for $1 \mathrm{~min}$, and $72^{\circ} \mathrm{C}$ for $1 \mathrm{~min}$ with a thermal cycler. This was followed by a final extension at $72^{\circ} \mathrm{C}$ for $10 \mathrm{~min}$ to ensure complete product extension. PCR products were visualized on a $1.0 \%$ agarose gel with ethidium bromide. The expression of each mRNA was normalized to the GAPDH mRNA signal of the same samples. Densitometry was performed with NIH Image software.

In vitro analysis. The SV-40 transformed rat lung vascular endothelial cells, TRLEC, were established at Institute of Cytosignal Research, Inc. (Tokyo, Japan) and kindly provided by Dr. Tsurufuji (10). TRLEC showed cobblestone morphology by light microscopy and we confirmed TRLEC as endothelial cells by the presence of factor VIII antigen (DAKO, Glostrup, Denmark) and by the uptake of acetylated LDL (Biomedical Technologies Inc., Cambridge, MA). TRLEC were grown on DMEM (Invitrogen) supplemented by $10 \%$ FBS (Invitrogen), $100 \mathrm{U} / \mathrm{mL}$ penicillin G, and $100 \mu \mathrm{g} / \mathrm{mL}$ streptomycin (Invitrogen) and incubated at $37^{\circ} \mathrm{C}$ in a humidified atmosphere of $5 \% \mathrm{CO}_{2}$ and air. For exposure to hypoxia, subconfluent TRLEC were placed in an APM-30D incubator (ASTEC, Fukuoka, Japan) at $37^{\circ} \mathrm{C}$ in a humidified $1 \% \mathrm{O}_{2} / 5 \% \mathrm{CO}_{2} / 94 \% \mathrm{~N}_{2}$ atmosphere.

After 24 and 48 h exposure to hypoxia, cells were gently rinsed twice with PBS and scraped quickly into Isogen (Nippon Gene, Toyama, Japan) to isolate total RNA, followed by RT-PCR, as described above. The primers used for BMPRII cDNA amplification were synthesized according to the sequence reported by Vitt et al. (11). Amplifications of BMPR Ia, Smad1, Smad8, Id-1, and ET-1 cDNA were achieved by using specific primers based on published GenBank sequences (Table 1).

To extract whole cell protein, cells were gently rinsed and resuspended in modified RIPA buffer (50 mM Tris, $150 \mathrm{mM} \mathrm{NaCl}, 1 \mathrm{mM}$ EDTA, $1 \%$ NP-40, and $0.25 \%$ sodium deoxycholate) in the presence of $1 \mathrm{mM}$ sodium orthovanadate, $1 \mathrm{mM} \mathrm{NaF}$, and proteinase inhibitors. The protein content was determined and Western blotting analysis was performed, as described above.

Statistical analysis. All results were expressed as the mean \pm SEM. Between-group comparison of the means was performed by one-way ANOVA, followed by Fisher's protected least significant difference test for multiple comparisons of the means. A value of $p<0.05$ was considered statistically significant.

\section{RESULTS}

Assessment of hypoxia-induced pulmonary hypertension. The weight ratio of RV to the LV+IVS was gradually increased after $3 \mathrm{~d}(0.34 \pm 0.020), 7 \mathrm{~d}(0.40 \pm 0.02)$, and $14 \mathrm{~d}$ $(0.58 \pm 0.02)$ of exposure to hypoxia compared with normoxia $(0.31 \pm 0.01)$ (normoxia versus 7 and $14 \mathrm{~d}, p<0.05$ ). These results indicated right ventricular hypertrophy caused by pulmonary hypertension as previously reported (12).

Expression of BMPRII and BMP-regulated Smads. Immunoreactivity for BMPRII was widely distributed in rat lungs: bronchial epithelium and EC of the elastic and muscular pulmonary artery (Fig. 1, $A-C$ ). Although the immunoreactivity in each cell was distinctive in normoxic rats, there was a great difference in the intensity of immunostaining in the EC of small muscular pulmonary arteries between normoxic and hypoxic rats. The expression of BMPRII was definitely decreased by $14 \mathrm{~d}$ in hypoxic rats (Fig. $1 C$ ). Therefore, to analyze BMPR signaling, we focused on the EC of small muscular pulmonary arteries (resistance vessels).

Table 1. Sequences of the primers with the accession numbers used for RT-PCR experiments

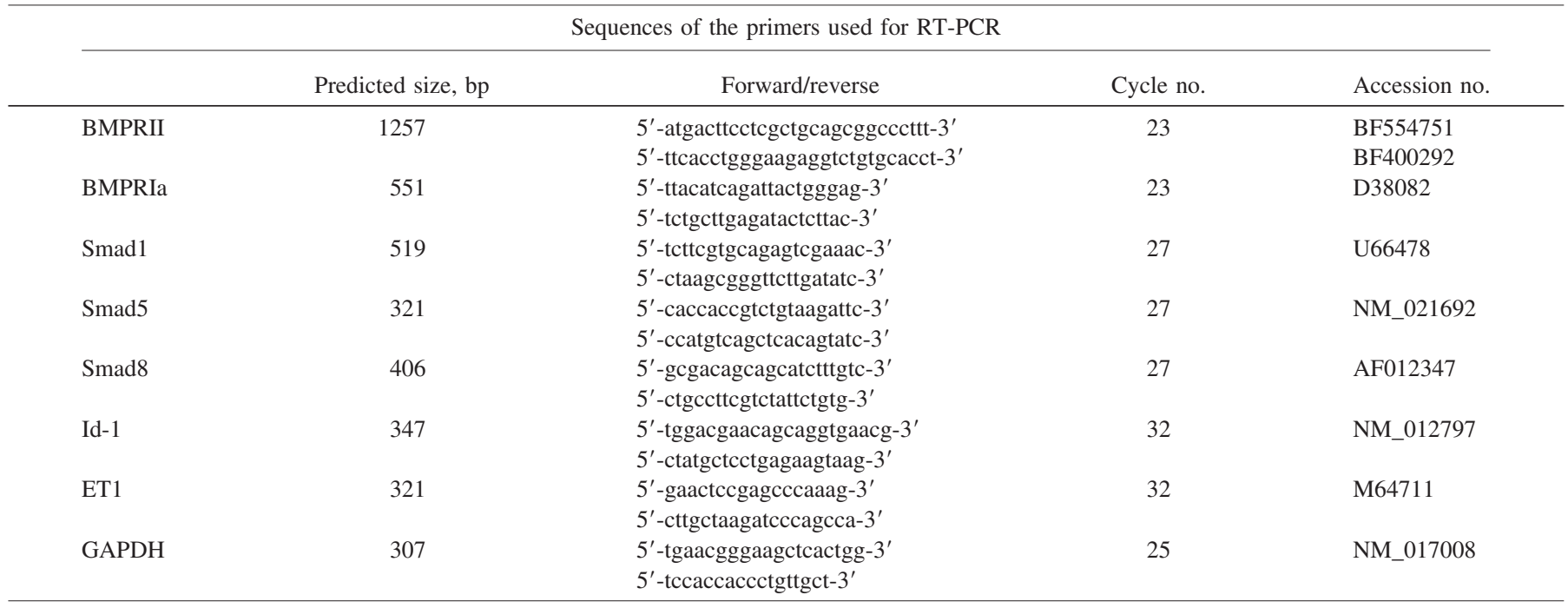


A

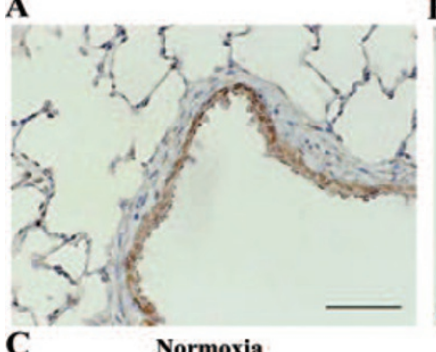

B
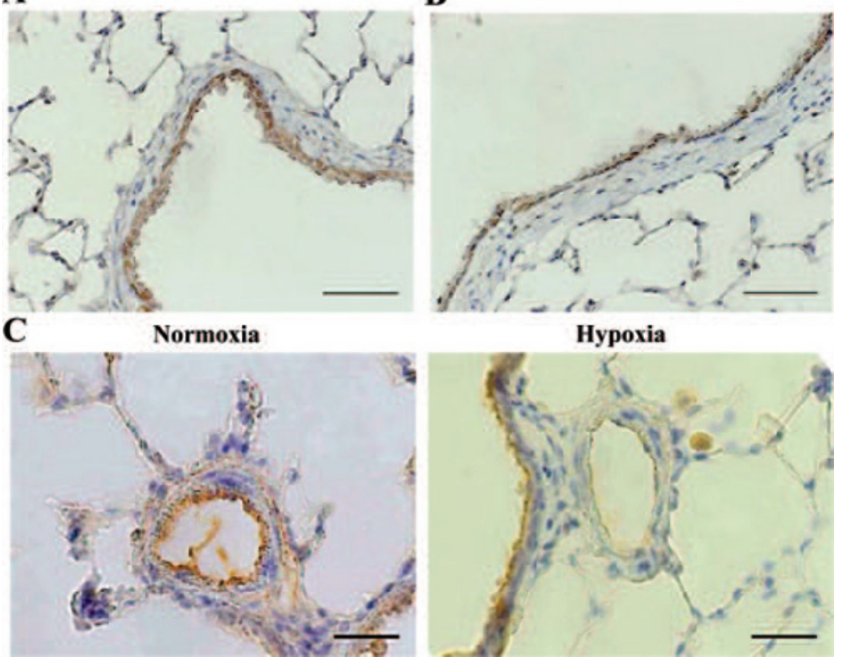

Figure 1. Representative photomicrographs of lung sections with immunohistochemical staining for BMPRII. (A) Bronchial epithelial cells and (B) endothelial cells of an elastic pulmonary artery demonstrate positive immunostaining in normoxic rats. Bars $=100 \mu \mathrm{m}$ : original magnification: $\times 200$. $(C)$ Immunohistochemical staining in a small muscular pulmonary artery under normoxia and $14 \mathrm{~d}$ hypoxia. Bars $=50 \mu \mathrm{m}$ : original magnification: $\times 400$.

To investigate BMPR signal transducers, immunoreactivity for Smad1, Smad5, and Smad8 was examined. In hypoxic rats, the expression of Smad5 and Smad8 protein was reduced in the EC of resistance vessels, similar to the BMPRII protein expression (Fig. 2, $A$ and $B$ ). On the other hand, Smad1 expression was increased by $14 \mathrm{~d}$ in hypoxic rats (Fig. $2 C$ ). Semi-quantification of positive immunostaining for BMPRII, Smad5, and Smad8 in resistance vessels revealed significant decrease in expression levels after chronic hypoxia (Fig. 3, $A-C)$. In contrast, the expression level of Smad1 in resistance vessels was markedly increased in hypoxic rats (Fig. 3D). In situ hybridization demonstrated that Smad1 mRNA was strongly expressed in the EC of resistance vessels after $7 \mathrm{~d}$ exposure to hypoxia (Fig. 2D), whereas it was weakly expressed in normoxic rats (data not shown). At $14 \mathrm{~d}$, Smad1
A

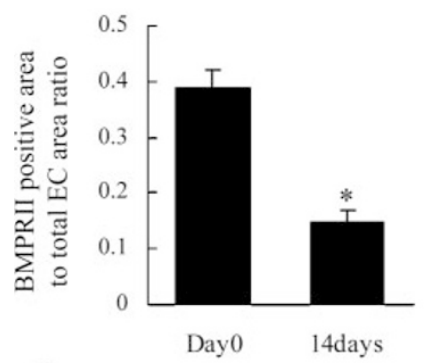

C

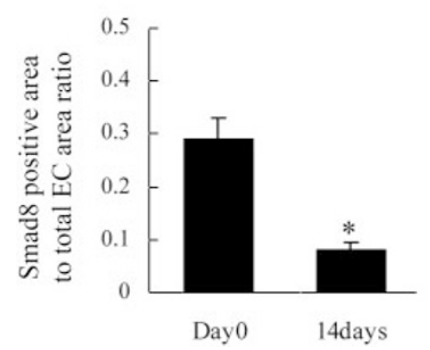

B

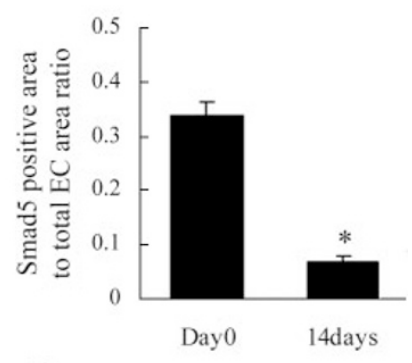

D

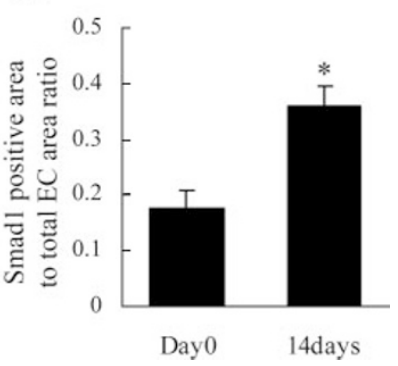

Figure 3. Semi-quantifications of expression of BMPRII and Smads in pulmonary muscular arteries under normoxia and 14 d hypoxia. $(A)$ BMPRII, (B) Smad5, (C) Smad8, (D) Smad1. Data are expressed as the mean $\pm \mathrm{SEM}$ $(n=15)$. *p $<0.01$ vs d 0 .

mRNA was reduced to the same extent as seen in normoxic rats. Thus, the expression of Smad1 mRNA in the EC of resistance vessels was transiently increased during the development of hypoxia-induced $\mathrm{PH}$.

Expression of ALK1 protein. Because Smad1 also acts as a downstream signal of transforming growth factor- $\beta$ (TGF- $\beta$ )/ activin receptor-like kinase1 (ALK1) pathway (13), we examined the expression of ALK1. Immunoreactivity for ALK1 was predominantly demonstrated in the EC of rat lung vessels. In contrast to BMPRII protein, the expression of ALK1 protein was increased in the EC of resistance vessels after chronic hypoxia (Fig. 4A). Western blotting showed a significant increase in ALK1 protein expression in lung tissues of hypoxic rats compared with normoxic rats (Fig. 4B). These

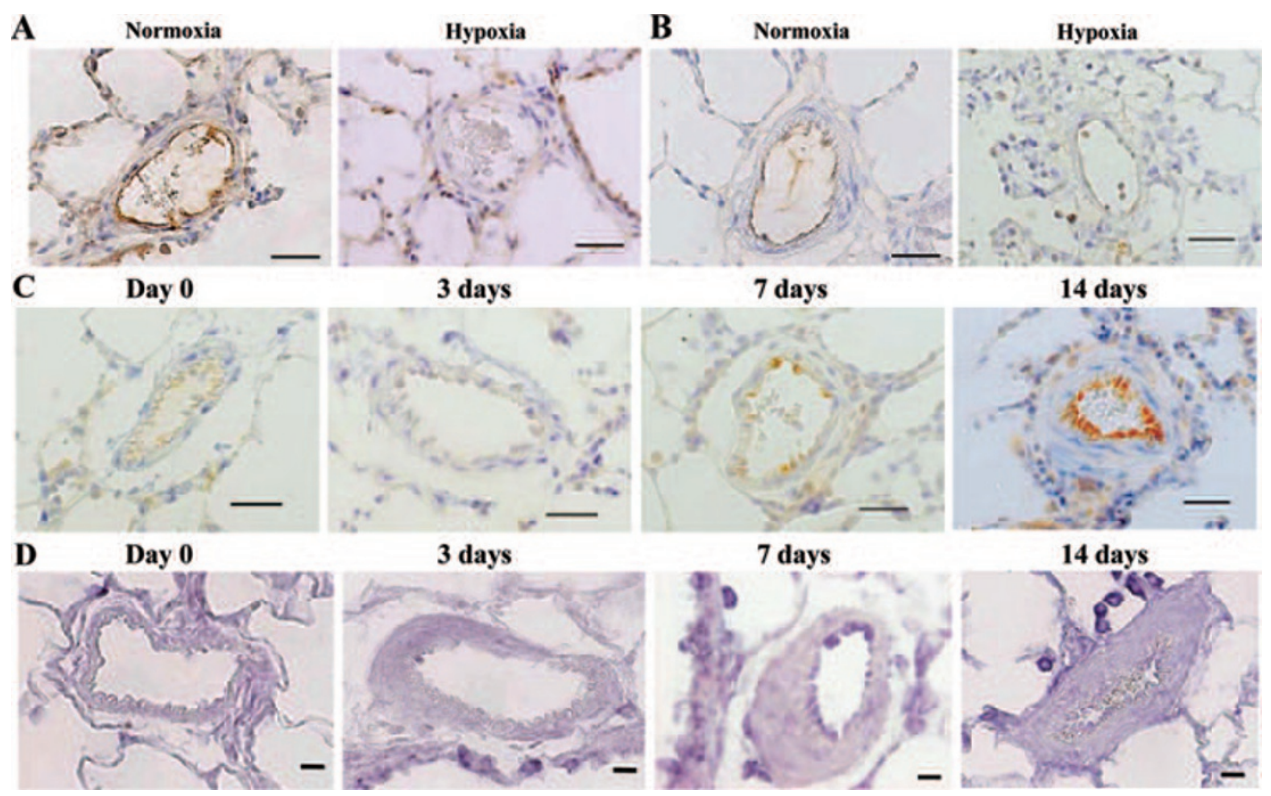

Figure 2. Changes in expression of BMPregulated Smads during chronic hypoxia. Immunohistochemical staining for Smad5 $(A)$ and Smad8 $(B)$ in a small muscular pulmonary artery under normoxia and $14 \mathrm{~d}$ hypoxia. Bars $=50 \mu \mathrm{m}$ : original magnification: $\times 400$. Immunohistochemical staining $(C)$ and in situ hybridization $(D)$ for Smad1 at d 0 and 3, 7 and $14 \mathrm{~d}$ after exposure to hypoxia. Bars $=10 \mu \mathrm{m}$ : original magnification: $\times 400$. 


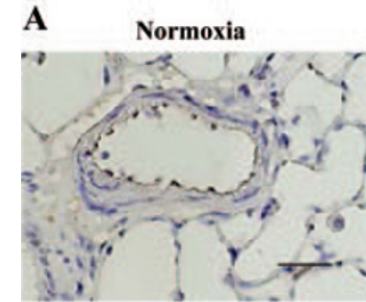

B
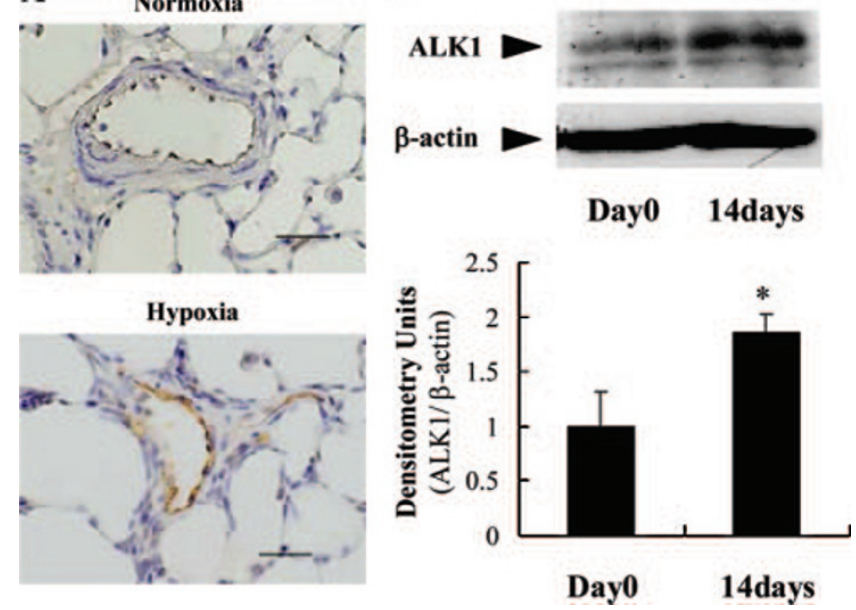

Figure 4. Changes in ALK1 expression during chronic hypoxia. (A) Immunohistochemical staining for ALK1 in a small muscular pulmonary artery under normoxia and $14 \mathrm{~d}$ hypoxia. Bars $=50 \mu \mathrm{m}$. $(B)$ Top: representative Western blots of ALK1 and $\beta$-actin at d 0 and $14 \mathrm{~d}$ after exposure to hypoxia. Bottom: semi-quantifications of Western blots. Data are expressed as the mean $\pm \operatorname{SEM}(n=3) .{ }^{*} p<0.05 v s \mathrm{~d} 0$.

results demonstrated that the expression patterns of BMPRII and ALK1 were opposite in the EC of resistance pulmonary vessels under chronic hypoxia.

Alteration of BMPR signaling in lung tissues of hypoxic rats. BMP-regulated Smads have to be phosphorylated to translocate into the nucleus and regulate the transcription of target genes. Immunohistochemistry was performed to investigate changes in phospho-Smad1/5/8 expression in normoxic and hypoxic rats. Phospho-Smad1/5/8 expression in the EC of resistance vessels was reduced by $14 \mathrm{~d}$ in hypoxic rats compared with normoxic rats (Fig. 5A). Western blotting showed significant time-dependent decrease in phospho-Smad1/5/8 protein expression during chronic hypoxia (Fig. $5 B$ ). In addition, the amount of Id-1 mRNA, one of the target genes for BMPR signaling, was significantly reduced during the development of PH (Fig. 6, $A$ and $B$ ).

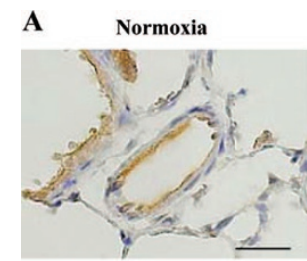

\section{B}
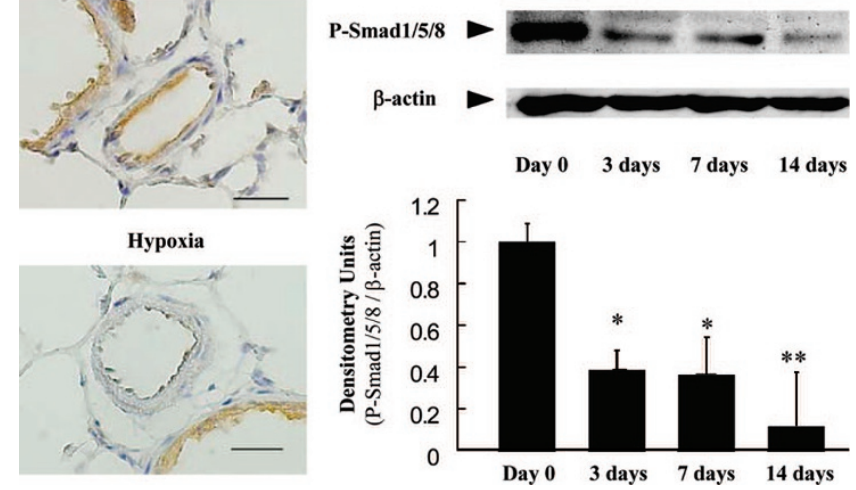

Figure 5. Changes in the expression of phospho-Smad1/5/8 during chronic hypoxia. (A) Immunohistochemical staining for phospho-Smad1/5/8 in a small muscular pulmonary artery under normoxia and $14 \mathrm{~d}$ hypoxia. Bars $=$ $50 \mu \mathrm{m}$. (B) Top: representative Western blots of Phospho-Smad1/5/8 and $\beta$-actin at $\mathrm{d} 0$ and 3, 7, and $14 \mathrm{~d}$ after exposure to hypoxia. Bottom: semi-quantifications of Western blots. Data are expressed as the mean \pm SEM $(n=3) . * p<0.01 v s \mathrm{~d} 0 ; * * p<0.001 v s \mathrm{~d} 0$.
A

Id-1

GAPDH

B

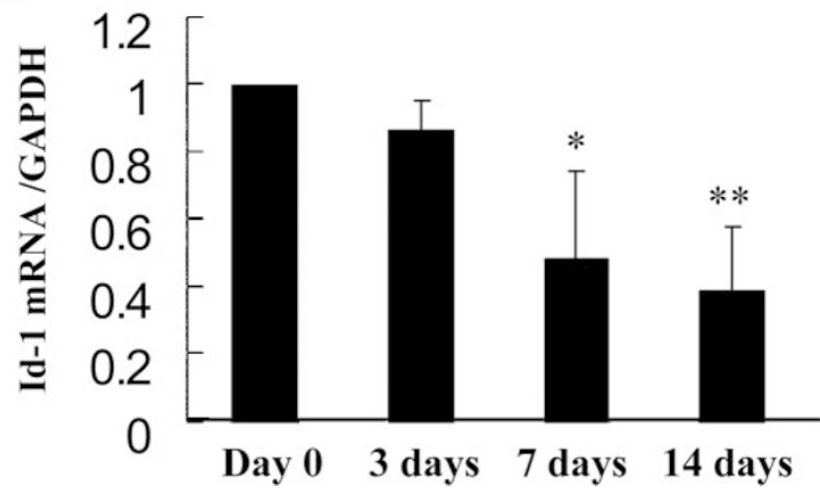

Figure 6. Changes in the expression of Id-1 during chronic hypoxia. (A) Representative electrophoreses of RT-PCR product from rat lung at $\mathrm{d} 0$ and 3,7 , and $14 \mathrm{~d}$ after exposure to hypoxia. (B) Semi-quantification of expression of Id-1 mRNA. Data are expressed as the mean \pm SEM $(n=3) . * p<0.05$ vs $\mathrm{d} 0$; * $p<0.01$ vs $\mathrm{d} 0$.

Alteration of BMPR and BMPR signaling in vitro under hypoxia. Using TRLEC, we analyzed the effect of hypoxia on the BMPR signaling pathway in vitro. The expression of ET-1 mRNA, which is known to be induced by hypoxia in EC, was increased after exposure to hypoxia (Fig. 7A). Conversely, after $48 \mathrm{~h}$ hypoxia, mRNA expression levels of BMPRIa and BMPRII decreased to $75.2 \pm 3.4 \%$ and $47.8 \pm 7.3 \%$ of those seen in untreated TRLEC (Fig. 7B). Smad8 mRNA expression decreased to $43.8 \pm 3.9 \%$, although Smad1 and Smad5 mRNA were not significantly altered (Fig. $7 B$ ). In addition, Western blotting showed that the expression of phosphoSmad1/5/8 protein decreased to $54.7 \% \pm 7.8 \%$ during $48 \mathrm{~h}$ hypoxia (Fig. $7 C$ ), and the expression of Id-1 mRNA also decreased to $45.9 \pm 7.6 \%$ after $48 \mathrm{~h}$ hypoxia (Fig. $7 B$ ).

\section{DISCUSSION}

Since the BMPRII gene has been identified as one of the causative genes of IPAH $(2,3)$, several investigations have implicated the essential role of BMPR in the pathogenesis of IPAH, as well as APAH $(5,6)$. However, little is known about the intracellular alterations in BMPR signaling during the development of PAH. In this study, we have shown that, 1) reduced expression of BMPRII was observed in lung tissues of Sprague-Dawley rats exposed to chronic hypoxia, 2) the expression of BMPR signal transducers, phospho-Smad1/5/8 and Id-1, was simultaneously decreased, and 3) these changes in expression were clearly localized to endothelial cells of resistance pulmonary arteries. Furthermore, using rat lung vascular endothelial cells, we revealed that, 4) acute hypoxia induced a reduction of BMPRIa and BMPRII expression, leading to the alteration of BMPR signal transducers in pulmonary EC. 
A

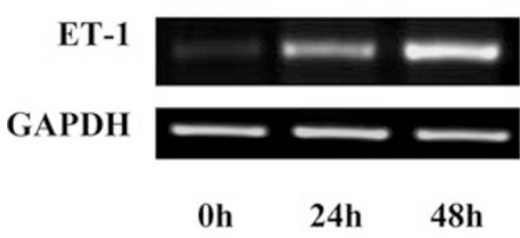

B
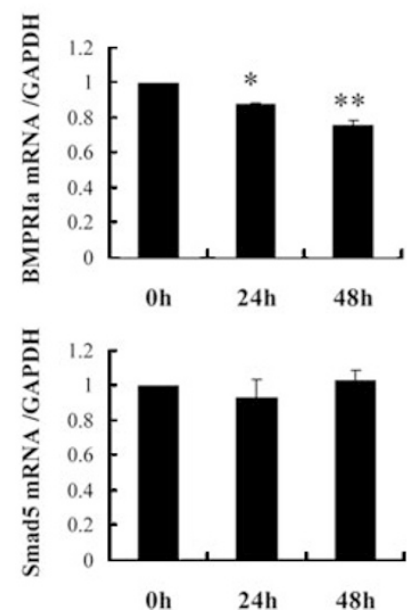

C
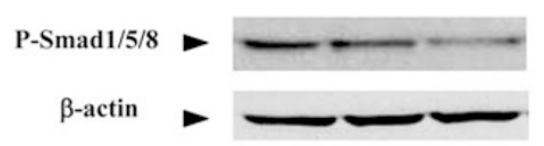

$0 \mathrm{~h}$
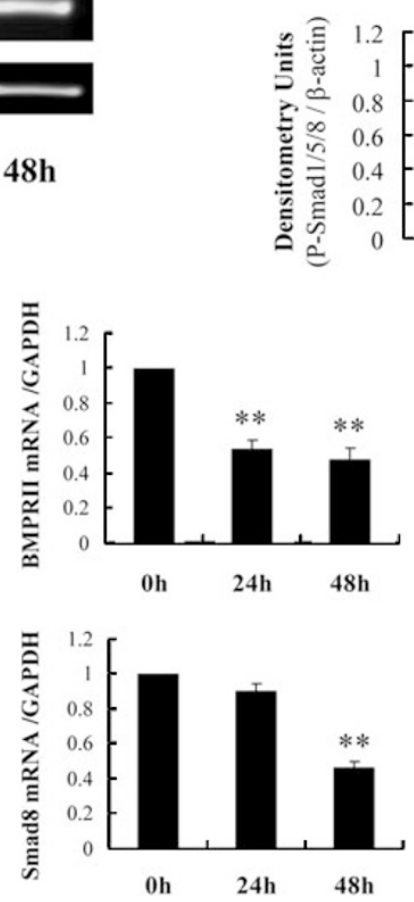

Under diverse circumstances with pulmonary hypertension, early changes in pulmonary vasculature commonly occur at the level of resistance pulmonary artery, as medial hypertrophy with peripheral muscularization. Although previous reports addressed that BMPRII in pulmonary artery smooth muscle cells (PASMC) was involved in the mechanism of PH $(14,15)$, little attention has been paid to the relevance of the BMPR signaling pathway in pulmonary artery EC, despite of the evidence for the presence of endothelial dysfunction in the initiation and the progression of $\mathrm{PH}(16,17)$. In this study, BMPRII expression was predominantly observed in EC of normal rat pulmonary artery rather than PASMC. This finding was consistent with the localization of BMPRII expression in human lungs (5). We performed Western blotting for BMPRII using whole lung lysate, and there was no significant difference in expression among control rats and 3-, 7-, and 14-d hypoxic rats (data not shown). However, image analysis using immunohistochemistry showed a marked reduction of BMPRII expression in the EC of resistance pulmonary arteries under chronic hypoxia. Although the levels of BMPRIa expression in rat lungs have not been determined, it has been reported that BMPRIa expression was reduced in pulmonary EC of patients with IPAH and APAH (6). Thus, the reduced expression of BMPR complex in the EC of resistance vessels may play an important role in the pathogenesis of hypoxia-induced $\mathrm{PH}$.

To clarify changes in the downstream signaling of BMPR, phosphorylated BMP-regulated Smads were investigated. In hypoxic rats, the expression of phospho-Smad1/5/8 in the EC of resistance pulmonary vessels was clearly reduced, and the amount of phospho-Smad1/5/8 protein was reduced with time. In addition, an in vitro study using TRLEC revealed that
Figure 7. Changes in the expression of BMPR signaling molecules in TRLEC exposed to $1 \% \mathrm{O}_{2}$ for 24 and $48 \mathrm{~h}$. (A) Representative electrophoreses of the RT-PCR product of ET-1 mRNA. Similar results were obtained in two other experiments. (B) Semi-quantifications of RT-PCR results for BMPRIa, BMPRII, Smad1, Smad8, and Id-1. Data are expressed as the mean $\pm \operatorname{SEM}(n=3) . * p<$ 0.05 vs $0 \mathrm{~h} ; * * p<0.01$ vs 0 h. (C) Top: representative Western blots of P-Smad1/ $5 / 8$ and $\beta$-actin at 0,24 , and $48 \mathrm{~h}$ after exposure to hypoxia. Bottom: semiquantification of Western blots. Data are expressed as the mean $\pm \operatorname{SEM}(n=4)$. $* p<0.01$ vs $\mathrm{d} 0 ; * * p<0.001$ vs $\mathrm{d} 0$. hypoxia induced the reduction of mRNA expression of BMPRIa and II, and simultaneous reduction of phospho-Smad1/ 5/8 protein and Id-1 mRNA expression. These results suggest that hypoxia attenuates BMPR signal transduction in the EC of the pulmonary artery, which may contribute to the development of PAH. Our present results, however, were in slight discordance with those of Takahashi et al. (18), who recently reported the significance of P38 MAPK pathway rather than Smad pathway in the pulmonary vasculature of hypoxic rats, with no significant changes in the expression of phosphoSmad1/5/8 after exposure to hypoxia. We have no explanation for this discordance except for the age of rats used.

Among a variety of downstream targets for BMPR signaling, Id-1 plays a crucial role in the behavior of EC (19). Id-1 is a bHLH transcription factor lacking a DNA-binding lesion to act as a dominant-negative regulator of bHLH proteins (20). It is also known as a proangiogenic factor and is abundantly expressed during blood vessel formation (21). The increased expression of Id-1 was observed in a variety of cancer cells exposed to hypoxia (22). This phenomenon could account for tumor angiogenesis and progression in the hypoxic microenvironment. In our study, however, the expression of Id-1 mRNA was decreased in TRLEC exposed to acute hypoxia and lung tissues of hypoxic rats. The expression pattern of Id-1 under hypoxia appears to be different between cancer and pulmonary vascular endothelial cells. One of the important structural changes in chronic hypoxia-induced pulmonary hypertension is the loss of blood vessels in the pulmonary circulation (23), which is in stark contrast to the marked angiogenesis in the systemic circulation in hypoxia (24). Despite the increased level of vascular endothelial growth 
factor (VEGF) in the lung (25), no evidence of new capillary formation was detected (26). It is reported that Id-1 knockdown inhibits the VEGF-induced angiogenic process (27). The suppression of VEGF-elicited vessel formation due to decreased expression of Id-1 might be one of the reasons for vascular rarefaction in the lungs of hypoxic rats.

Interestingly, the expression of nonphosphorylated Smads exhibited different patterns in pulmonary EC during exposure to hypoxia. An in vivo study showed that Smad5 and Smad8 protein levels were decreased similar to BMPRII, phosphoSmads and Id-1. In contrast, the levels of Smad1 protein were markedly increased in the EC of the resistance pulmonary artery. It has been reported that Smad1 and Smad5 are also phosphorylated via ALK-1, which is TGF- $\beta$ type I receptor (28) and expressed predominantly in EC (13). Thus, Smad1 and Smad5 expression may be influenced through both BMPR and ALK1 in pulmonary EC. Recent reports have shown that TGF- $\beta_{1}$ /ALK- 1 were elevated during the development of PH caused by increased pulmonary blood flow (29), and the expression level of TGF- $\beta$ protein was clearly increased in human lung tissues with PH (30). In addition, heterozygous mutations in the ALK1 gene caused hereditary hemorrhagic telangiectasia 2, which, not infrequently, leads to PAH (31). These findings suggest that the TGF- $\beta$ /ALK1 signaling pathway is also important in association with PAH. In this study, we showed that hypoxia allowed an increase in the expression of ALK1 protein in the ECs of resistance vessels in vivo. Smad1 in EC might be more affected by TGF- $\beta /$ ALK1 signaling otherwise Smad5/8 might be more affected by BMPR signaling. Accordingly, the balance between BMPR signaling and TGF- $\beta$ /ALK1 signaling in pulmonary EC may be important in the development of PAH.

Taken together, the in vivo and in vitro data indicate that the BMPR pathway localized in pulmonary artery EC is involved in the pathogenesis of hypoxia-induced pulmonary hypertension. Although further investigations are needed to clarify the precise mechanism of its regulation and the function of BMPR signaling in pulmonary vascular remodeling, the alteration of BMPR signal transduction exists as a common intracellular mechanism of many kinds of pulmonary arterial hypertension.

Acknowledgments. The authors thank Dr. Matsuura (Department of Pathology, School of Allied Health Science, Faculty of Medicine, Osaka University, Osaka, Japan) for providing advice and expertise.

\section{REFERENCES}

1. Simonneau G, Galie N, Rubin LJ, Langleben D, Seeger W, Domenighetti G, Gibbs S, Lebrec D, Speich R, Beghetti M, Rich S, Fishman A 2004 Clinical classification of pulmonary hypertension. J Am Coll Cardiol 43:5S-12S

2. Deng Z, Morse JH, Slager SL, Cuervo N, Moore KJ, Venetos G, Kalachikov S, Cayanis E, Fischer SG, Barst RJ, Hodge SE, Knowleset JA 2000 Familial primary pulmonary hypertension (Gene PPH1) is caused by mutations in the bone morphogenetic protein receptor-II gene. Am J Hum Genet 67:737-744

3. Thomson JR, Machado RD, Pauciulo MW, Morgan NV, Humbert M, Elliott GC, Ward K, Yacoub M, Mikhail G, Rogers P, Newman J, Wheeler L, Higenbottam T, Gibbs JS, Egan J, Crozier A, Peacock A, Allcock R, Corris P, Loyd JE, Trembath RC, Nichols WC 2000 Sporadic primary pulmonary hypertension is associated with germline mutations of the gene encoding BMPR-II, a receptor member of the TGF-beta family. J Med Genet 37:741-745

4. Derynck R, Zhang YE 2003 Smad-dependent and Smad-independent pathways in TGF-beta family signaling. Nature 425:577-584
5. Atkinson C, Stewart S, Upton PD, Machado R, Thomson JR, Trembath RC, Morrell NW 2002 Primary pulmonary hypertension is associated with reduced pulmonary vascular expression of type II bone morphogenetic protein receptor. Circulation 105:1672-1678

6. Du L, Sullivan CC, Chu D, Cho AJ, Kido M, Wolf PL, Yuan JX, Deutsch R, Jamieson SW, Thistlethwaite PA 2003 Signaling molecules in nonfamilial pulmonary hypertension. N Engl J Med 348:500-509

7. Beppu H, Kawabata M, Hamamoto T, Chytil A, Minowa O, Noda T, Miyazono K 2000 BMP type II receptor is required for gastrulation and early development of mouse embryos. Dev Biol 221:249-258

8. Beppu H, Ichinose F, Kawai N, Jones RC, Yu PB, Zapol WM, Miyazono K, Li E, Bloch KD 2004 BMPR-II heterozygous mice have mild pulmonary hypertension and an impaired pulmonary vascular remodeling response to prolonged hypoxia. Am J Physiol Lung Cell Mol Physiol 287:L1241-L1247

9. Sasano H, Suzuki T, Matsuzaki Y, Fukaya T, Endoh M, Nagura H 1999 Messenger ribonucleic acid in situ hybridization analysis of estrogen receptors $\alpha$ and $\beta$ in human breast carcinoma. J Clin Endocrinol Metab 84:781-785

10. Shimada K, Takahashi M, Tanzawa K 1994 Cloning and functional expression of endothelin-converting enzyme from rat endothelial cells. J Biol Chem 269:1827518278

11. Vitt UA, Mazerbourg S, Klein C, Hsueh AJ 2002 Bone morphogenetic protein receptor type II is a receptor for growth differentiation factor-9. Biol Reprod $67: 473-480$

12. Hislop A, Reid L 1976 New findings in pulmonary arteries of rats with hypoxiainduced pulmonary hypertension. Br J Exp Pathol 57:542-554

13. Ota T, Fujii M, Sugizaki T, Ishii M, Miyazawa K, Aburatani H, Miyazono K 2002 Targets of transcriptional regulation by two distinct type I receptors for transforming growth factor-beta in human umbilical vein endothelial cells. J Cell Physiol 193:299-318

14. West J, Fagan K, Steudel W, Fouty B, Lane K, Harral J, Hoedt-Miller M, Tada Y, Ozimek J, Tuder R, Rodman DM 2004 Pulmonary hypertension in transgenic mice expressing a dominant-negative BMPRII gene in smooth muscle. Circ Res 94:11091114

15. Zhang S, Fantozzi I, Tigno DD, Yi ES, Platoshyn O, Thistlethwaite PA, Kriett JM, Yung G, Rubin LJ, Yuan JX 2003 Bone morphogenetic proteins induce apoptosis in human pulmonary vascular smooth muscle cells. Am J Physiol Lung Cell Mol Physiol 285:L740-L754

16. Budhiraja R, Tuder RM, Hassoun PM 2004 Endothelial dysfunction in pulmonary hypertension. Circulation 109:159-165

17. Rabinovitch M Cellular and molecular pathobiology of pulmonary hypertension conference summary. Chest 2005;128:642S-646S

18. Takahashi H, Goto N, Kojima Y, Tsuda Y, Morio Y, Muramatsu M, Fukuchi Y 2006 Downregulation of type II bone morphogenetic protein receptor in hypoxic pulmonary hypertension. Am J Physiol Lung Cell Mol Physiol 290:L450-L458

19. Valdimarsdottir G, Goumans MJ, Rosendahl A, Brugman M, Itoh S, Lebrin F, Sideras P, ten Dijke P 2002 Stimulation of Id1 expression by bone morphogenetic protein is sufficient and necessary for bone morphogenetic protein-induced activation of endothelial cells. Circulation 106:2263-2270

20. Norton JD, Deed RW, Craggs G, Sablitzky F 1998 Id helix-loop-helix proteins in cell growth and differentiation. Trends Cell Biol 8:58-65

21. Volpert OV, Pili R, Sikder HA, Nelius T, Zaichuk T, Morris C, Shiflett CB, Devlin MK, Conant K, Alani RM 2002 Id1 regulates angiogenesis through transcriptional repression of thrombospondin-1. Cancer Cell 2:473-483

22. Löfstedt T, Jögi A, Sigvardsson M, Gradin K, Poellinger L, Pahlman S, Axelson H 2004 Induction of Id2 expression by hypoxia-inducible factor-1. J Biol Chem 279:39223-39231

23. Rabinovitch M, Gamble W, Nadas AS, Miettinen OS, Reid L 1979 Rat pulmonary circulation after chronic hypoxia: hemodynamic and structural features. Am J Physiol 236:H818-H827

24. Griffioen AW, Molema G 2000 Angiogenesis: potentials for pharmacologic intervention in the treatment of cancer, cardiovascular diseases, and chronic inflammation. Pharmacol Rev 52:237-268

25. Christou H, Yoshida A, Arthur V, Morita T, Kourembanas S 1998 Increased vascular endothelial growth factor production in the lungs of rats with hypoxiainduced pulmonary hypertension. Am J Respir Cell Mol Biol 18:768-776

26. Sobin SS, Tremer HM, Hardy JD, Chiodi HP 1983 Changes in arteriole in acute and chronic hypoxic pulmonary hypertension and recovery in rat. J Appl Physiol 55:1445-1455

27. Sakurai D, Tsuchiya N, Yamaguchi A, Okaji Y, Tsuno NH, Kobata T, Takahashi K, Tokunaga K 2004 Crucial role of inhibitor of DNA binding/differentiation in the vascular endothelial growth factor-induced activation and angiogenic processes of human endothelial cells. J Immunol 173:5801-5809

28. Goumans MJ, Lebrin F, Valdimarsdottir G 2003 Controlling the angiogenic switch a balance between two distinct TGF- $\beta$ receptor signaling pathways. Trends Cardiovasc Med 13:301-307

29. Mata-Greenwood E, Meyrick B, Steinhorn RH, Fineman JR, Black SM 2003 Alterations in TGF-betal expression in lambs with increased pulmonary blood flow and pulmonary hypertension. Am J Physiol Lung Cell Mol Physiol 285:L209-L221

30. Botney MD, Bahadori L, Gold LI 1994 Vascular remodeling in primary pulmonary hypertension. Potential role for transforming growth factor-beta. Am J Pathol 144:286-295

31. Harrison RE, Flanagan JA, Sankelo M, Abdalla SA, Rowell J, Machado RD, Elliott CG, Robbins IM, Olschewski H, McLaughlin V, Gruenig E, Kermeen F, Halme M, Raisanen-Sokolowski A, Laitinen T, Morrell NW, Trembath RC 2003 Molecular and functional analysis identifies ALK-1 as the predominant cause of pulmonary hypertension related to hereditary haemorrhagic telangiectasia. J Med Genet 40:865-871 